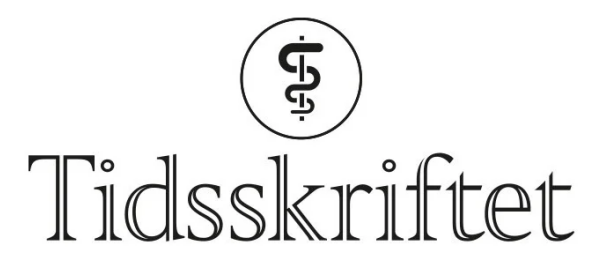

DEN NORSKE LEGEFORENING

\title{
Bruk tavlen
}

\author{
FRA REDAKTØREN
}

\section{PETTER GJERSVIK}

(f. 1952) er medisinsk redaktør i Tidsskriftet. Han er førsteamanuensis og undervisningsleder i hudog veneriske sykdommer ved Det medisinske fakultet i Oslo.

Email: petter.gjersvik@medisin.uio.no

\section{Tavlen er et undervurdert pedagogisk hjelpemiddel. Den kan brukes som både alternativ og supplement til PowerPoint}

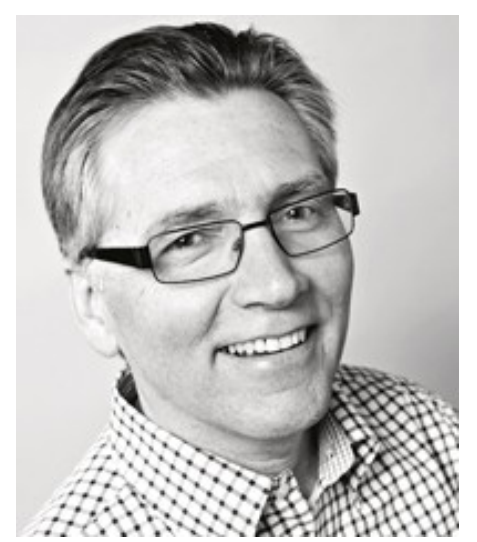

Foto: Einar Nilsen

Undervisning i medisin er i stor grad basert på direkte kontakt mellom lærer og studenter ansikt til ansikt. I kliniske smågrupper blir spørsmål stilt, diskutert og besvart, meninger utvekslet, feil påpekt og tilbakemeldinger gitt - muntlig, direkte, kontinuerlig og uavhengig av tekniske begrensninger. Forelesninger gir læreren en mulighet til å forklare prinsipper, skape oversikt og gjennomgå spesielt vanskelige emner for mange studenter om gangen (1). I tidligere tider var det ikke uvanlig at en foreleser begrenset seg til å forelese, dvs. lese opp fra et manus, gjerne uten eller med minimal bruk av tavle - «to read a paper», som det heter på engelsk. Nå bruker nesten alle forelesere visuelle hjelpemidler, men tavlen er gjerne byttet ut - først var det lysark (overheads), senere lysbilder og de siste årene har det vært PowerPoint.

PC-baserte presentasjonsverktøy som PowerPoint har hatt uvurderlig betydning for kvaliteten på forelesningene og har gjort det mye enklere for forelesere å forberede seg og å oppdatere sine forelesninger (22). Brukt riktig er PowerPoint en velsignelse for både lærere og studenter. Men det kan lett misbrukes, bl.a. med kjedelige, overfylte og/eller altfor 
mange bilder. PowerPoint kan svekke kontakten mellom lærer og tilhørere og stå i veien for budskapet. Fleksibiliteten er begrenset. Enkelte er sterkt kritiske til PowerPoint og hevder at programmet er både fordummende og det som verre er (3).

Det finnes stadig et alternativ til PowerPoint som er billig, lett tilgjengelig og lett å bruke: tavlen. En erfaren og dyktig foreleser ved Det medisinske fakultet i Oslo skriver på sin nettside: «Tavle er det mest miskjente pedagogiske virkemiddel i vår tid. Få ting gjør meg så rasende som når jeg kommer til et nymotens auditorium uten tavle» (4). J Jeg har prøvd ut hans (og andres) anbefaling om å basere enkelte forelesninger på tavlebruk og har erfart at det fungerer veldig bra - det føles rett og slett frigjørende! Kontakten med studentene blir bedre, og tempo og fremdrift kan tilpasses innspill og spørsmål fra auditoriet. Tavlen kan brukes til å skrive ned viktige ord, begreper og utsagn, gjerne basert på svar studentene har gitt på forelesers spørsmål underveis, og til å illustrere viktige poenger med enkle streker og figurer (5). God tavleundervisning betyr rett og slett at studentene må være aktive.

Etter mitt skjønn kan en tavle være helt avgjørende for en god forelesning. Det gjelder også når man må basere sin forelesning på PowerPoint - ja, særlig da, for underveis dukker det alltid opp spørsmål som krever en tavle for å få forklart et viktig poeng. Heldigvis er de fleste auditorier og andre undervisningsrom utstyrt med tavle, men ikke alle. I noen auditorier, blant annet på Rikshospitalet, er tavlen gjemt bak et lerret som brukes for projeksjon av PowerPoint-bilder. Dette er ikke optimalt, for flyten i dialogen lider hvis foreleser må bruke tid på å finne de riktige knappene på styringspanelet, heve lerretet, ta av lyset på projektor og tilpasse lyset i salen (og på tavlen) for så å skrive eller tegne på den. Ekstra frustrerende er det når det mangler kritt eller tusjpennene er tørre. Deretter er det samme vei tilbake til PowerPoint-presentasjonen. Det kan også være ønskelig å ha et PowerPoint-bilde på lerretet samtidig som man noterer på en tavle - da må tavle og lerret være plassert ved siden av hverandre.

Det er altså ikke slik at man enten bør bruke tavle eller PowerPoint. Studier tyder på at det nettopp er kombinasjonen og vekslingen mellom flere typer hjelpemidler som gir best undervisning (므). Og for all del: Også tavlebruk har sine minussider, slik som uforståelig håndskrift, dårlige tegninger og at foreleseren har ryggen til forsamlingen mens han eller hun snakker mot tavlen.

Dagens medisinstudenter bruker nettbaserte kunnskapskilder. Med PC, nettbrett eller smarttelefon har de tilgang til oppdatert og kvalitetssikret medisinsk informasjon med noen få tastetrykk. Lærernes PowerPoint-presentasjoner lastes opp fra nettet. Videofilmer av forelesninger ved ledende universiteter i utlandet er tilgjengelig på nett. Med bruk av epost, sms og app-er kommuniserer studentene med hverandre og lærerne om faglige og praktiske spørsmål. Om få år vil vi ha enda flere og mer brukervennlige pedagogiske hjelpemidler til disposisjon. Selv om det tar tid og krever mye ressurser å etablere velfungerende e-læringssystemer, er det ingen tvil om at e-læring er i ferd med å endre medisinsk utdanning og medisinsk praksis (7.).

En god forelesning i medisinstudiet er kjennetegnet av dialog mellom foreleser og tilhørere, variert bruk av pedagogiske hjelpemidler og at tempo og fremdrift er tilpasset studentenes forutsetninger. Tavlebruk er verken gammelmodig eller nostalgisk, men tvert imot moderne, direkte, dynamisk, intuitivt og fritt tilgjengelig - uten behov for strøm eller fungerende nettilgang.

\section{LITTERATUR}

1. Gjersvik P. Til forsvar for forelesningen. Tidsskr Nor Lægeforen 2006; 126: 2087. [PubMed]

2. Craig RJ, Amernic JH. PowerPoint presentation technology and the dynamics of teaching. Innovative High Educ 2006; 31: 147-6o. [CrossRef]

3. Tufte E. PowerPoint is evil. Wired. September 2003.

http://web.archive.org/web/20140415121014/http://archive.wired.com/wired/archive/11.og/ppt2.html 
(20.9.2014).

4. Wyller TB. Om forelesninger og klinikker i geriatri. http://folk.uio.no/tbwyller/undervisning.htm (20.9.2014).

5. Craig C. Essay on the teaching value of chalkboards. Inside Higher Education 1.1.2013. www.insidehighered.com/views/2013/04/01/essay-teaching-value-chalkboards (20.9.2014).

6. Meo SA, Shahabuddin S, Al Masri AA et al. Comparison of the impact of powerpoint and chalkboard in undergraduate medical teaching: an evidence based study. J Coll Physicians Surg Pak 2013; 23: 47-50. [PubMed]

7. Ruiz JG, Mintzer MJ, Leipzig RM. The impact of E-learning in medical education. Acad Med 20o6; 81: 207-12. [PubMed] [CrossRef]

Publisert: 28. oktober 2014. Tidsskr Nor Legeforen. DOI:10.4045/tidsskr.14.116o

(C) Tidsskrift for Den norske legeforening 2023. Lastet ned fra tidsskriftet.no 26. april 2023. 